\title{
Quantifying sheet erosion in agricultural highlands of Sri Lanka by tracking grain-size distributions
}

Tilak Hewawasam ${ }^{1, *}$ and Sandun Illangasinghe ${ }^{2}$

${ }^{1}$ Department of Geography, University of Peradeniya, Peradeniya, Sri Lanka.

${ }^{2}$ Department of Natural Resources, Sabaragamuwa University of Sri Lanka, Belihuloya, Sri Lanka.

${ }^{*}$ Corresponding author. E-mail: tilak@pdn.ac.lk 


\section{Quantifying sheet erosion in agricultural highlands of Sri Lanka by tracking grain-size distributions}

\section{Abstract}

The reduction of productivity in arable lands of the tropical highlands through intensified soil erosion is a major reason for food scarcity in many developing countries. Identifying soil erosion hot spots in highland agricultural croplands and monitoring the effectiveness of soil conservation are crucial for improving land management practices. This paper develops a low cost and efficient method to quantify the rate of soil loss caused by splash and sheet erosion, in-situ at the plot scale. This method assumes that textural differences between the topsoil and the underlying soil within the plot are due to erosion of the top layer. Grain size analyses conducted in agricultural soils of the Upper Uma Oya Catchment (UUOC) of Sri Lanka provided data to quantify splash or sheet erosion and deposition. Net soil loss from the plot was calculated based on rates of area weighted soil loss and deposition. The net splash and sheet erosion rate in the plot was $20 \mathrm{t} \mathrm{ha}^{-1} \mathrm{yr}^{-1}$, which is comparable with previous soil erosion results obtained in the area $\left(25 \mathrm{t} \mathrm{ha}^{-1} \mathrm{yr}^{-1}\right)$ at similar temporal and spatial scale and under the same agricultural use. This study suggests that approximately half of the total erosion in the UUOC area results from splash and sheet erosion, whereas the rest is driven by concentrated flow through rill and

gully erosion. This method is potentially transferable to other croplands as a robust approach for rapid measurement of splash and sheet erosion.

Keywords: Soil erosion, Soil loss, Soil conservation, Tropical 


\section{Introduction}

Soil erosion is recognized as one of the world's most serious environmental problems affecting steep lands in tropics since it significantly reduces the area of croplands available for food production (Pimentel, 2006). It is a natural process that occurs on lands under agriculture or natural vegetation, but its magnitude can be enormously increased in the agricultural lands depending on the land management practices. The lands under agriculture are much more vulnerable to soil erosion because the removal of the vegetation cover and repeated preparation by tillage exposes the surface to erosion. It directly reduces land productivity by reducing water availability, soil depth, soil organic content and essential plant nutrients. Further, soil erosion has many other secondary effects such as siltation in reservoirs, thereby reducing the generation of hydro-electricity, limiting water supplies for irrigation and impairing the quality of drinking water (Pimentel and Burgess, 2013). It has been estimated that the reservoirs of the world are losing their storage capacity at a rate of $1 \%$ per year due to siltation (Mahmood, 1987). Worldwide, soil erosion on croplands averages about $30 \mathrm{t} \mathrm{ha}^{-1} \mathrm{yr}^{-1}$ ranging from 0.5 to $400 \mathrm{t} \mathrm{ha}^{-1} \mathrm{yr}^{-1}$ (Pimentel et al., 1995). It has been estimated that about 10 million ha of lands are lost each year due to the intensified soil erosion under agriculture, thus reducing the croplands available (Pimentel and Burgess, 2013). At the global scale, rate of soil loss under the croplands is 10 to 40 times faster than the natural rates of soil replenishment (Pimentel and Burgess, 2013). This loss has been gravely noted in many areas of the developing world, especially in the humid tropics, where minimum attention is paid on land management. For an example, the average rate of soil loss due to erosion in India has been reported as $16.4 \mathrm{t} \mathrm{ha}^{-1} \mathrm{yr}^{-1}$ (Pandey and Chaudhari, 2010). In the Sierra Region of Ecuador, about $60 \%$ of the cropland has been abandoned from agriculture because of erosion and unsuitable land management (Southgate and Whitaker, 1992). In the Central Highlands of Sri Lanka, soil loss in lands under shifting cultivation and tobacco has been reported as high as $70 \mathrm{t} \mathrm{ha}^{-1} \mathrm{yr}^{-1}$ (Gunatilake and Vieth, 2000), which is about 100 times faster than the natural replacement rate (Hewawasam et al., 2003). Therefore, conservation of soil in the croplands and monitoring its success by quantifying soil loss rates are very decisive. 
The Central Highlands of Sri Lanka is an economically sensitive terrain, as it is the center for generating hydropower that supplies about $40-50 \%$ of the total power consumption in the country and, yet has arable lands for seasonal crops and tea (Fig. 1). This terrain was forested until the early nineteenth century, when the land was cleared at a regional scale, to make way for coffee and tea plantations (Wickramagamage, 1998). Subsequently, with the decline of tea production, some of the abandoned lands, characterized by steep slopes were converted to seasonal crops. Moreover, due to the inadequacy of arable lands, farmers have further extended their croplands into steeply sloped areas (Erabadupitiya, 2006). These areas are presently under seasonal crops without proper land management practices (Abegunawaradana and Gunathilaka, 1992; Samarakoon, 2004). As a result of rapid land use changes in the last two centuries, soil erosion has accelerated by several orders of magnitude over the natural replenishment rates (Hewawasam et al., 2003) and it has adversely affected the hydropower generation (Hewawasam, 2010), crop yield (Ananda et al., 2001) and surface water quality (Amarasekara et al., 2009).

A considerable amount of field data on erosion from the Central Highlands of Sri Lanka has been gathered at plot scale and reported for different land use. In these studies, soil loss rates have been measured at on-site sediment traps or at field runoff plots. However, some of the rates have been predicted from the universal soil loss equation (USLE) adjusted with parameters more suitable to Sri Lankan conditions. Soil loss rates in areas of tea plantations in the Central Highlands have been reported for three different land management practices: (1) seedling plots, without any soil conservation, soil loss equals $75 \mathrm{t} \mathrm{ha}^{-1} \mathrm{yr}^{-1}$; (2) unprotected seedling tea lands where soil losses range between $46 \mathrm{t} \mathrm{ha}^{-1}$ $\mathrm{yr}^{-1}$ and $18.5 \mathrm{t} \mathrm{ha}^{-1} \mathrm{yr}^{-1}$; (3) managed plots, where soil loss is low at $2 \mathrm{t} \mathrm{ha}^{-1} \mathrm{yr}^{-1}$ (ElSwaify and Krishnarajah, 1983). Hasselo and Sirkurajapathi (1965) identified that soil erosion patterns are seasonal, with very high erosion during the replanting period, amounting to rates as high as $72 \mathrm{t} \mathrm{ha}^{-1} \mathrm{yr}^{-1}$. Manipura (1972) elaborated on the importance of having a cover crop against surface run-off during replanting. His experiments showed a very low soil loss across mulched plots of $0.8 \mathrm{t} \mathrm{ha}^{-1} \mathrm{yr}^{-1}$ and higher values of $52 \mathrm{t} \mathrm{ha}^{-1}$ $\mathrm{yr}^{-1}$ for unmulched plots, both under same monsoon rain. For the lands under seasonal crops in the Central Highlands of Sri Lanka, high rates of soil erosion have been reported. Experiments that were carried out at plot scale revealed that the soil loss under tobacco, 
capsicum and carrot equal $70 \mathrm{t} \mathrm{ha}^{-1} \mathrm{yr}^{-1}, 38 \mathrm{t} \mathrm{ha}^{-1} \mathrm{yr}^{-1}$ and $18 \mathrm{t} \mathrm{ha}^{-1} \mathrm{yr}^{-1}$, respectively (Krishnarajah, 1982). Samarakoon and Abegunawardane (1995) also reported high rates of soil loss for potato crop in steep slopes of the Central Highlands estimated at $24 \mathrm{tha}^{-1}$ $\mathrm{yr}^{-1}$ on average. A team of agricultural engineers and soil scientists of the Ministry of Forestry and Environment, reviewed the most accurate estimates of soil loss based on field studies and presented soil erosion rates for different land use types (Ministry of Forestry and Environment, 1995, as cited by Gunatilake and Vieth, 2000). Accordingly, the average soil loss reported for vegetable plots (referred as "market gardens") in the Central Highlands is $25 \mathrm{t} \mathrm{ha}^{-1} \mathrm{yr}^{-1}$. Similarly, a large number of plot studies elsewhere in the tropical regions showed high rates of soil loss under croplands since these lands are very susceptible to soil erosion after removal of natural vegetation, especially under harsh climates (Dadson et al., 2003; Correchel et al., 2006; Verbist et al., 2010). Labri`ere et al. (2015) quantitatively reviewed a large data set of soil loss measurements at the plot scale from 21 countries in the humid tropics and showed that soil erosion is very intense on steep slopes where soils have been exposed and were kept bare for various reasons. Accordingly, soil loss rates vary significantly depending on the land use type: from $0.2 \mathrm{t}$ $\mathrm{ha}^{-1} \mathrm{yr}^{-1}$ for well vegetated croplands with soil conservation measures to $25 \mathrm{t} \mathrm{ha}^{-1} \mathrm{yr}^{-1}$ for croplands without proper management. The implementation of vegetation and soil related conservation practices in tropical region can reduce erosion even by up to $99 \%$. Therefore, conservation of soil by applying suitable conservation methods and testing of their effectiveness is imperative for croplands in the humid tropics for their long-term sustainability. However the application and monitoring of soil conservation measures depend on availability of simple, rapid and robust assessment tools that can be readily employed to quantify soil erosion rate together with understanding of erosion mechanisms.

In the Central Highlands of Sri Lanka, the focus of research over the last few decades, has been on catchment scale studies, after impoundment of large hydropower reservoirs under the Accelerated Mahaweli Project, commenced in 1977. Measuring of siltation rates in reservoirs (NEDECO, 1984) and, gauging of rivers for suspended loads (NEDECO, 1984; Wallingford, 1995; Hewawasam et al., 2003; Illangasinghe and Hewawasam, 2015) have been used to calculate spatially averaged erosion rates in the 
contributing catchments. Whilst catchment-scale spatially-averaged erosion rate studies may be more suitable than plot-scale studies to predict the siltation rates in reservoirs, these studies cannot resolve the local effects of erosion. Sediment loads as monitored by river load gauging, may not accurately reflect erosion rates within the catchment, as it effectively averages out, and masks other processes operating at the meso- and microscales. To provide an example, spatially average erosion rate estimated by river load gauging in a catchment of the tropical island of Sumatra has exceeded soil loss measured in erosion plots by a factor 3 to 10 . In this catchment, $60 \%$ of the total sediment load, is from an area of $<20 \%$ of the total catchment, indicating that severe erosion is localized within the catchment ("soil erosion hot spots") (Verbist et al., 2010). Therefore, catchment-scale studies may not resolve, or identify, the sites directly affected by high rates of soil erosion, where immediate attention for conservation is needed. Thus, the main advantages of plot scale studies are the identification of erosion hot spots, providing the means to assess the impact of specific cultivation methods, determine the effects of soil-crop combinations on erosion rates and, the framework to test different conservation methods at the field scale (Correchel et al., 2006). Geochemical tools can be applied at plot scale to measure erosion rates with high accuracy. For example, radionuclides of ${ }^{137} \mathrm{Cs}$ can be used to determine erosion rates at a decennial temporal scale (Collinsa et al., 2001; Correchel et al., 2006; Foucher et al., 2014), which can be used for soil conservation and land management practices. However, these methods have a high experimental cost and are difficult to be applied frequently for a rapid assessment of soil erosion rate in the scope of a regular monitoring programme. This study focuses on the development and validation of a simple method that quantifies soil erosion at the plot scale in agricultural lands, through an experimental study in the Central Highlands of Sri Lanka (Fig. 1). The key assumption supporting this study is that fine particles on the soil surface are selectively removed by overland flow and that the armor layer is increasingly enriched in coarser soil particles. This paper documents the methodology behind this conceptual framework, including field and laboratory procedures, and then provides, an experimental study resulting in the determination of soil erosion rates. Finally, the inferred soil erosion rates are compared with rates that have reported by independent 
erosion assessments based on soil loss measurements, river load gauging, ${ }^{137} \mathrm{Cs}$ fallout radionuclide measurements and ${ }^{10} \mathrm{Be}$ cosmogenic nuclide measurements.

\section{Field site, theory and methods for validation}

\subsection{Erosion processes in the Central Highlands of Sri Lanka}

The main erosion process observed in the study area is water erosion that is characteristic to a landscape affected by heavy monsoons. Sheet erosion is the common soil loss mechanism in croplands, but rill and gully erosion are of major concern in poorlymaintained lands. As rills and gullies can easily be observed by local farmers, current conservation practices are biased towards the control of erosion by concentrated flow. The farmer's perception of sheet erosion is limited because sheet erosion is difficult to be identified in croplands until the harvesting time. Stocking and Murnaghan (2000) reported that presence of eroded features such as pedestals, root exposures and armor layers are the clear indicators of cropland under extensive sheet erosion. But identification of these features in the field remains difficult for farmers since it needs profound field experience. Therefore, although splash and sheet erosion are the dominant processes contributing to soil loss on agricultural lands, current conservation practices fail to recognize, or mitigate for their affects. If left unmanaged, this may lead to an unprecedented environmental disaster in the Central Highlands.

Different techniques have been used to measure soil erosion rates in the Central Highlands of Sri Lanka (Stocking and Clark, 1999; Hewawasam et al, 2003; Dissanayake et al, 2010; Hewawasam, 2010, etc.). Almost all of these studies have estimated rates of soil erosion including splash, sheet, rill and gully erosion at catchment scale. Crucial, quantitative assessment on the extent of sheet erosion in the Central Highlands is still limited. Therefore, in this study, we propose a method which adopts the principle of comparing topsoil particle size distribution with corresponding non-disturbed subsoil as a soil erosion indicator to assess sheet erosion rates at plot scale over the seasonal time scale. Applicability of this method was tested in the field, in the Perawella area, in the Upper Uma Oya Catchment (UUOC) (Fig. 1). This field site is affected by high anthropogenic soil erosion (Stocking and Clark, 1999; Hewawasam et al, 2003; Dissanayake et al, 2010). 


\subsection{Study plot at Perawella, Central Highlands of Sri Lanka}

The case study is an agricultural plot located in mountainous terrain, with altitudes between $1183 \mathrm{~m}$ and $1176 \mathrm{~m}$, in the Upper Uva basin, one of the major vegetable cultivation areas in Sri Lanka (Fig. 1). The plot is located in the Upper Uma Oya Catchment, part of the Mahaweli basin of Sri Lanka, encompassing an area of $400 \mathrm{~m}^{2}$ (Fig .1). Within the area, the cultivation pattern occurs as paddy land in the bottom of the valley and vegetable cultivation on the hillslopes. Human population expansion has increased pressure on the land and caused cultivation to expand on to the steepest hillsides. The cultivation of vegetables in the area has even been extended to steep slopes up to an altitude of $1500 \mathrm{~m}$ (Clark et al., 1998). The UUOC $\left(98 \mathrm{~km}^{2}\right)$ is being monitored for river loads by the Mahaweli Authority of Sri Lanka since it is the contributing catchment to one of the main hydropower reservoirs in the country. The area is uniformly underlain by crystalline metamorphic rock and the soil type in the upper hillslopes, according to the USDA soil taxonomy, is Ultisol.

Figure 1 (a) Map of Upper Uma Oya Catchment (UUOC), Sri Lanka, illustrating sampling locations, as follows: closed black square - study plot at Perawella for grain size distribution analysis; open black circle - river gauging station; and closed white square study plot at Hakgala natural forest reserve where natural (geological) erosion rate has been quantified using in-situ produced cosmogenic nuclides. The broken white line demarcates Upper Uma Oya Catchment. (b) Sketch showing the boundary of the study plot used in the UUOC to estimate soil erosion rates, showing sampling points in closed circles. The area has been terraced for cultivation and the crop at time of sampling was eggplant (Solanum melongena). (c) Land use map derived from aerial photographs at 1 : 20000 scale by the Survey Department, Sri Lanka.

The pattern of vegetable cultivation in the UUOC is influenced by monsoonal variations. Some of the hilly lands are used to cultivate potatoes during major or "Maha" monsoon (November - January), and other vegetables (beans, cabbages, and eggplant, etc.) are cultivated during the minor or "Yala" monsoon (May - July). In addition to the two major 
monsoons, an intermediate monsoon also exists resulting a short dry period. Mean annual rainfall in the study area is $2000 \mathrm{~mm}$ to $2500 \mathrm{~mm}$. The prominent land use types in the UUOC are natural forest (26\%), mixed forest (1\%), plantations (9\%), Kandyan forest gardens $(7 \%)$, paddy $(6 \%)$, tea (17\%), annual rainfed crops $(14 \%)$, vegetables $(14 \%)$ and scrubs and grasslands (4\%) (Diyabalanage, 2012). In the Upper Uma Oya catchment (ca. $98 \mathrm{~km}^{2}$ ) where the field site is located, the prominent land conservation practices are stone bunds, life fences and hedge rows. Vegetables are largely grown on sloping lands that are converted in to series of terraces by manual labor.

A rectilinear-shaped block in this terraced landscape was selected to quantify soil loss (Fig. 1). The long axes of the study plot are parallel to the general slope, and are orientated east - west. The total area of the study plot is $400 \mathrm{~m}^{2}$, with an average local slope of $20-25^{\circ}$. The crop at time of sampling was eggplant (Solanum melongena). Prior to planting, the plot had been manually ploughed, such that the top- and sub-soil layers were well mixed to a depth of c. $20 \mathrm{~cm}$. The study plot encloses 6 terraced benchers, each spanning $\sim 2 \mathrm{~m}$ in width, and artificially leveling the plot to $\sim 1 \%$ (Fig. 1). The maximum and minimum elevations of the study plot are $1183 \mathrm{~m}$ and $1176 \mathrm{~m}$, respectively. Soil sampling was conducted along four traversers (south-west to north-east direction).

\subsection{Theoretical framework}

The erosion process is controlled by the action and interaction of many factors: the most prominent natural factors are meteorology, especially precipitation and, geology, topography, soil composition and land use (Toy et al., 2002). Precipitation is considered the main factor since the field site is situated in a wet and tropical region where intense monsoon rains prevail at least twice a year. Water plays a major role in eroding soil particles by splash and overland flow detachment. Therefore, in this study, our intention is to develop a method to quantify the integrated splash and sheet erosion for a small agricultural plot.

The rain kinetic energy of a particular rain storm may disintegrate the structure of the soil. In this process, soil particles are selectively removed from the surface of the soil profile (Fig. 2) and transported along the hillslope by overland flow. It has been observed that particle selection is a very common phenomenon during the processes of sheet 
erosion (Foster and Meyer, 1975). Quiquereza et al. (2008) demonstrated that this process selectively sorted, and removed, fine particles $(<0.63 \mathrm{~mm})$ from the topsoil of a vineyard in Burgundia, and concentrated the coarse fraction $(>2 \mathrm{~mm})$ at the surface. Alberts et al. (1980) demonstrated that the size of the particles transported by sheet erosion is markedly finer than that of the particles transported by concentrated flow. Consequently, the coarse particles remain on the soil surface, which could ultimately lead to sand enrichment of the topsoil. It is therefore postulated that in soils affected by splash and sheet erosion, the topsoil material tends to be dominated by coarse particles, as fine particles are removed by laminar flow (Fig .4). In this scenario, the enrichment of the topsoil in coarse particles is expected to be related to rainstorms of a particular magnitude and duration (Fig. 3). The threshold grain size may vary at the micro-scale, due to varying local conditions, including rain drop kinetic energy, soil texture and structure, soil organic content, local slope angle, etc. The coarser fraction above the threshold size is enriched on surface and the resulting layer can be referred to as armor layer (Stocking and Murnaghan, 2000) (Fig. 2). The depth of this layer changes from place to place according to the magnitude of erosion. Thus, below the armor layer soil can be considered to have the reference grain size distribution. In brief, we consider that the presence of an armor layer indicates that sheet erosion has occurred, and that the depth of the armor layer is indicative of the amount of erosion (Fig. 3). We hereby assume that contribution of bioturbation, mechanical settling of fine particles or pedogenesis to this textural change are negligible between two consecutive crop seasons.

Figure 2 Conceptual diagram showing erosional processes on the hillslope. Open circles and closed circles illustrate fine and coarse soil particles, respectively. (a) Splash erosion detaches soil particles from the surface by rain drop kinetic energy. (b) Fine particles are selectively removed by overland flow. (c) Coarser particles are enriched in the topsoil forming an armor layer while fine particles are transported along the slope by overland flow.

\subsection{Sampling}


In this study, the field plot was subjected to land preparation before the onset of the monsoonal season. It was ensured that the top- and sub-soils were well mixed to a depth of $20 \mathrm{~cm}$, removing the armor layer from the previous crop season. In this study, land preparation was undertaken by traditional methods, to mimic the farming practices in the Central Highlands. With the onset of a new rainstorm, loose fine soil particles are removed from the surface layer by splash and overland flow detachment leading to the development of a new armor layer. According to our measurements at the field, the maximum depth of the armor layer that developed was about $1 \mathrm{~cm}$. It is recognized that the magnitude and intensity of rainfall will affect the rates of splash and sheet erosion and thereby the depth of the armor layer, and that it expected that different depths of armored layers will develop.

In this study, the samples were collected 6 months after the land preparation. To validate the principle in the field and to study splash and sheet erosion, ten soil samples were collected from the surface (referred to here as topsoil) using systematic simple random sampling on all terrace levels. The soil samples were taken by excavating $15 \mathrm{~cm} \times 15 \mathrm{~cm} \times$ $1 \mathrm{~cm}$ pits. In order to establish a reference level, ten additional soil samples were collected from below the $1 \mathrm{~cm}$ (subsoil) at the corresponding pits. The samples were reduced by cone and quarter method to get a representative sample for grain size analysis.

The soil samples were then oven dried at $100^{\circ} \mathrm{C}$. Dry soil samples were subjected to sieve analysis through $4.75,2.36,1.18,0.6,0.3,0.15$, and $0.075 \mathrm{~mm}$ sieves. The retained weight of individual sieves was measured by an analytical balance. These were converted to weight percentages of the total weight of the sample. This practice was performed for all sample pits. Pit-specific graphs were constructed, using retained percentage of topsoil sample (circle point line Fig. 4) and subsoil sample (square point line in Fig. 4), for individual grain sizes (white symbols) and for cumulative weights (dark grey symbols). The annotated 'depositional points' indicate where the fine fraction is enriched in the topsoil; and the annotated 'erosion points' indicate where the fine fraction is depleted in the topsoil. Also presented are the cumulative weight percentages $(\mathrm{P})$ of fine particles below the threshold particle size in the topsoil layer, with respect to the subsoil sample (Fig. 3). 
Figure 3 Methodology for estimating soil losses of a cropland under seasonal crops. Prior to study, the topsoil of the land is well mixed during land preparation, such that previously developed armor layers are removed and the upper part of the soil profile becomes homogenized. The graph presents four grain size distribution curves; (i) fractional weight percentage of a topsoil (open circle) (ii) fractional weight percentage of a subsoil (open square) (iii) cumulative weight percentage of a topsoil (solid circle) (iv) cumulative weight percentage of a subsoil (solid square) in a test pit of a cropland after land preparation (e.g.; after six months). The intercept point (T) of the two fractional curves indicates the particular grain size for switching from erosion of fine particles to enrichment of coarse particles. The grain size at this intercept is referred to as the threshold grain size (T) in this paper. The coarser fraction, which is greater than the threshold grain size, is retained on the soil surface forming the armor layer. The eroded cumulative weight percentage of fine particles ( $\mathrm{P}$ in the equation 2 ) below the threshold particle size can be obtained from the graph (X\% - Y \%).

To determine erosion/deposition rates, dry bulk density of individual soil samples needs to be determined. In order to calculate the density, $220 \mathrm{~cm}^{3}$ volumes of soil sample were dried at $100^{\circ} \mathrm{C}$. Then, the final weight of the sample was detected and the dry bulk density was calculated (Table 1).

\subsection{Sheet erosion/deposition calculation}

Volume of sampling pit (V) is expressed by using the area of the soil sampling pit and depth of the topsoil sampling,

$$
V=a \times h\left(\mathrm{~cm}^{3}\right)
$$

Where, $a$ is sample pit area and $h$ is depth of the top soil. Eroded soil mass M is given by,

$$
M=V \times \rho \times P(\mathrm{~g})
$$

Where, $\rho$ is soil density, which was measured in each sampling pit and $\mathrm{P}$ is the cumulative percentage of fine fraction below the threshold particle size (Fig. 3). This 
value of $\mathrm{P}$ is calculated by subtracting the cumulative percentage of fine fraction below the threshold particle size in the topsoil from that of the percentage in the subsoil. P was measured in a representive soil sample from the pit; hence P measured in the sample is equal to the $\mathrm{P}$ of the eroded soil mass in the pit. Then, the local sheet erosion rate $(\mathrm{E})$ of each sampling pit is calculated by dividing soil loss mass by sampling pit area. In depositional sites, a similar method can be applied to quantify the deposition rates, D $\left(\mathrm{g} / \mathrm{cm}^{2}\right)$.

Figure 4 Particle size distributions in the topsoil and subsoil in the Perawella plot. Open circle- fractional weight of topsoil, open square- fractional weight of subsoil, solid circlecumulative weight of topsoil and solid square- cumulative weight of subsoil.

$$
E=\frac{M}{a}\left(\mathrm{~g} / \mathrm{cm}^{2}\right)
$$

\subsection{Mapping net soil losses}

Spatially distributed patterns of sheet erosion and deposition within the studied plot were analyzed by interpolation of soil erosion and deposition rates. Subsequently, soil erosion and deposition mass of individual segments were calculated using mean erosion/deposition rate and corresponding area. Net soil loss of the studied plot was calculated by subtracting the total mass of sediment deposition from the mass of soil loss by erosion. The soil erosion map of the study plot was derived by interpolating a raster surface from local measurements of soil erosion and deposition using an inverse distance weighted (IDW) technique in the ArcGIS 10.2 software.

\section{Results and discussion}

\subsection{Textural difference between the topsoil and subsoil}

The cumulative percentage of the fine fractions (below the threshold particle size) in the 10 sampling pits range from 2 to $27 \%$ (Table 1). In eight of the sampling pits (SP-1, SP- 
2, SP-3, SP-4, SP-5, SP-6, SP-8, and SP-12) the retained cumulative percentages of coarse fractions were higher in topsoil than those of the reference grain size distribution of the corresponding subsoil sample (Fig. 5). Below a particular grain size, the said percentages become comparatively lower in topsoil than the reference grain size distribution of the corresponding subsoil (Fig. 5). In this study, we consider that this particular grain size is the threshold grain size for a particular sampling pit. The fine fraction below the threshold particle size is selectively removed by water through sheet erosion, expectedly as other causes for textural changes are insignificant. Above, it was noted that bioturbation, mechanical settling of fine particles, illuviation of smaller particles into the pores and pedogenesis (Phillips, 2001; Phillips, 2007; Veldkamp, 2002), may also influence the upper part of the soil profile - however, these processes occur over a different temporal scale. The phenomena of removing fine particles from the topsoil layer through sheet erosion is recognized as a rapid mechanism, taking place only over a 6 months period after the mixing of the soil layer by the tillage. Importantly, any long term textural residual produced by natural soil redistribution processes is eliminated by the land preparation, of which the upper soil (up to $20 \mathrm{~cm}$ ) is thoroughly mixed during the land preparation. In two sampling pits (SP-9 and SP-10), the retained percentage of fine fractions are higher in the topsoil than in the subsoil indicating that deposition has taken place at these sites (Fig. 4). The threshold particle size ranged from $0.3 \mathrm{~mm}$ to 1.4 mm within the study plot (Fig. 4 and Table 1). The threshold particle size varied among sampling pits. Further, investigation of local variation in the threshold particle size is beyond the scope of this paper.

\subsection{Net rate of sheet erosion}

The equation 3 can now be used to calculate the rate of sheet erosion (E) or deposition (D) using the data of eroded or deposited percentage of fine fraction below the threshold particle size $(\mathrm{P})$ and dry soil bulk density $(\rho)$. Dry bulk densities vary from $1.1 \mathrm{~g} \mathrm{~cm}^{-3}$ to $1.6 \mathrm{~g} \mathrm{~cm}^{-3}$ in the study plot (Table 1). Local soil erosion rates range between 3 and $27 \mathrm{~g}$

$\mathrm{cm}^{-2}$, whereas deposition rates vary from $18 \mathrm{~g} \mathrm{~cm}^{-2}$ to $43 \mathrm{~g} \mathrm{~cm}^{-2}$. Notably, soil erosion is observed in the upper terraces of the experimented plot, although at different rates (SP-1, SP-2, SP-3, SP-4, SP-5, SP-6, SP-8, and SP-12); whereas, deposition is observed on the 
lowest terraces (SP-9 and SP-10) and at the bottom of the slope (Fig. 1). In order to derive a spatially-averaged erosion estimate for the entire plot, point measures of erosion and deposition rates were interpolated (Fig. 5). A net rate of sheet erosion of $1.2 \mathrm{~kg} \mathrm{~m}^{-2}$ was calculated for the entire plot using eroded and deposited sediment weights. This rate represents the net sheet erosion for this plot for six months from August to January, where monthly average rainfall is $\sim 200 \mathrm{~mm}$. The monthly average rainfall is based on rainfall data of 11 years covering 6 gauging stations in the study area. The monthly average rainfall in this area for the other part of the year from February to July is 131 $\mathrm{mm}$, or 0.66 times lower than the study period. Therefore, we can estimate the net sheet erosion during the unmeasured period being 0.66 times the sheet erosion rates measured for the period August to January. The resulting rate is $0.8 \mathrm{~kg} \mathrm{~m}^{-2}$. This calculation is based on the assumption that land management operations within the plot will not influence soil conditions; hence the temporal variation of sheet erosion within the plot is essentially influenced by rainfall variability. Though this assumption is not perfectly accurate, this is the best estimate for the unmeasured season.

\subsection{Comparison of soil erosion rates over different spatial and temporal scale}

In the wider region, proximal to the experimental plot, local erosion rates have been estimated and reported by the Ministry of Forestry and Environment (Gunatilake and Vieth, 2000). The annual sheet erosion rate is estimated at $20 \mathrm{t} \mathrm{ha}^{-1} \mathrm{yr}^{-1}$, i.e. the combination of the measured $12 \mathrm{t} \mathrm{ha}^{-1}$ for the 6 month period between August and January, and the estimated $8 \mathrm{tha}^{-1}$ for the period between February to July. This rate is comparable to the soil loss rates that are reported for agricultural lands with vegetables crops ( $\left.25 \mathrm{t} \mathrm{ha}^{-1} \mathrm{yr}^{-1}\right)$, by the Ministry of Forestry and Environment of Sri Lanka (Ministry of Forestry and Environment, 1995, as cited by Gunatilake and Vieth, 2000). Dissanayeke et al. (2010) have measured soil erosion rates on croplands in the Upper Uma Oya catchment on a similar slope, close to our study site, using ${ }^{137} \mathrm{Cs}$ fallout radionuclides and their rates are 44 and $22 \mathrm{t} \mathrm{ha}^{-1} \mathrm{yr}^{-1}$, for potato cultivation and pasture, respectively. It is notable that their soil erosion rates are comparable to those measured in

this study. In contrast, Clark et al. (1998) estimate rates of 59 to $79 \mathrm{t} \mathrm{ha}^{-1} \mathrm{yr}^{-1}$ (Clark et al., 1998) for a similar area, however, these rates were determined for a larger area (Fig. 
6). The net soil erosion rate measured by our method gives a rate of erosion across a small plots as a result of sheet erosion, whereas rates derived by Clark et al. (1998) include areas affected by sheet, rill and gully erosion. This comparison might suggest that approximately half of the total soil erosion in the Upper Uma Oya catchment area is operated by sheet erosion.

Table 01. Local measures of soil erosion and deposition in the agricultural plot at Perawella. Note that deposition has been taken place only in SP-09 and SP-10 sampling pits.

\begin{tabular}{lccccc}
\hline $\begin{array}{c}\text { Sample } \\
\text { number }\end{array}$ & $\begin{array}{c}\text { Threshold } \\
\text { grain size } \\
(\mathrm{mm})\end{array}$ & $\begin{array}{c}\text { Soil } \\
\text { density } \\
\left(\mathrm{g} \mathrm{cm}^{-3}\right)\end{array}$ & $\begin{array}{c}\text { Cumulative } \\
\text { eroded/deposited } \\
\text { percentage }(\mathrm{P})\end{array}$ & $\begin{array}{c}\text { Soil mass } \\
(\%)\end{array}$ & $\begin{array}{c}\text { Local soil } \\
\text { erosion/deposition } \\
\text { rate }\left(\mathrm{g} \mathrm{cm}^{-2}\right)\end{array}$ \\
\hline SP-01 & 0.3 & 1.4 & 11.5 & 3622.5 & 0.16 \\
SP-02 & 0.5 & 1.5 & 2 & 675 & 0.03 \\
SP-03 & 1.4 & 1.6 & 10 & 3600 & 0.16 \\
SP-04 & 0.35 & 1.1 & 5 & 1237.5 & 0.06 \\
SP-05 & 1.26 & 1.3 & 20 & 5850 & 0.26 \\
SP-06 & 0.52 & 1.3 & 18 & 5265 & 0.23 \\
SP-08 & 1.3 & 1.2 & 19 & 5130 & 0.23 \\
SP-09 & 0.9 & 1.5 & 12 & 4050 & 0.18 \\
SP-10 & 1.4 & 1.6 & 27 & 9720 & 0.43 \\
SP-12 & 0.45 & 1.5 & 18 & 6075 & 0.27 \\
\hline
\end{tabular}

The monitored river loads can be used to infer a spatially average erosion rate for the UUOC as $16 \mathrm{t} \mathrm{ha}^{-1} \mathrm{yr}^{-1}$ (Hewawasam et al, 2003). Interestingly, the spatially average erosion rate of the UUOC is also in agreement with the net sheet erosion rate that is here reported for the experimental plot (Fig. 6). However, comparing soil losses measured at the plot scale with spatially-averaged erosion rates at the catchment scale is not practicable, as different soil erosion processes are occurring at these spatial scales (de Vente and Poesen, 2005). As evidence, in the tropical island of Sumatra, the catchment 
scale erosion rates have exceeded plot scale soil loss rates by a factor 3 to 10 (Verbist et al 2010). Therefore, even though the spatially averaged erosion rate of the UUOC is similar to the erosion rate at our study plot, significant heterogeneity of erosion is expected leading to different rates of erosion within the catchment due to several reasons: (i) Sheet erosion is the dominant erosional process at the plot scale in croplands and it may not prevail in the other land use types and morphologies of the catchment, (ii) The crop type of the experimental plot represents about $14 \%$ of the total land area in the UUOC and $27 \%$ is covered by forest and $17 \%$ is under tea cultivation (Diyabalanage, 2012). It is known that the areas with high vegetation density erode at a rate that is similar to the natural erosion rate, regardless of whether the type of vegetation is natural or anthropogenic (Vanacker et al., 2007a). Therefore, maximum sediment supply to the fluvial system is likely generated from the vegetable lands where our field site is situated whereas the lands under other land use types erode at lower rates. (iii) Land management and soil conservation practices change significantly within the catchment influencing erosion and soil transfers within the catchment.

Figure 5 Soil erosion map of the study plot. The map was derived by interpolating measured soil erosion and deposition rates using ArcGIS 10.2.

Many researchers use a soil loss tolerance level (or $\mathrm{T}$ factor), defined as the maximum rate of annual soil erosion that will permit a high level of crop productivity. It is now possible to establish pre-anthropogenic (geological) erosion rates in an eroding profile with the aid of in-situ produced cosmogenic nuclides such as ${ }^{10} \mathrm{Be}$ and ${ }^{26} \mathrm{Al}$. This provides information on the natural processes of erosion driven by climate and tectonics, and cosmogenic nuclide erosion studies are insensitive to recent anthropogenic perturbations (Hewawasam, et al., 2003). There is a large data set of background erosion rates measured in soil and fluvial sediments of the Central Highlands of Sri Lanka (Hewawasam et al., 2003; Von Blanckenburg et al., 2004; Vanacker et al., 2007b, Hewawasam et al., 2013). Background erosion rates in a small plots at Hakgala in the UUOC, which is completely covered by pristine rain forest, have been measured by using in-situ produced cosmogenic ${ }^{10} \mathrm{Be}$ in minerals grains of soil. Topographical and climatic 
conditions of this small forested plot are similar to our study plot at Perawella. The resulting background erosion rates are about $3 \mathrm{t} \mathrm{ha}^{-1} \mathrm{yr}^{-1}$ (Hewawasam et al, 2013). Interestingly, the comparison of the geologic erosion processes and their rates with those operating today, and measured directly at Perawella, clearly show that erosion (at Perawella) has increased by a factor of 7 , due to deforestation and agriculture. These findings are in agreement with previous studies in the Central Highlands of Sri Lanka (Fig. 6) (Hewawasam, 2003).

\section{Conclusions}

In this study we have proposed a simple, rapid, robust and direct methodology for quantifying soil loss at the plot scale. The proposed and validated method is a novel, simple and inexpensive means of quantifying sheet erosion by measuring differences in the textural composition between a coarser armor layer in the topsoil and the presumably undisturbed subsoil. The method is based on the assumption that fine particles in the topsoil are selectively removed by water erosion and coarser material is enriched at the top of the soil profile. This approach was demonstrated in an experimental study of an agricultural plot in the Central Highlands of Sri Lanka. Net sheet erosion rates of $20 \mathrm{tha}$

${ }^{1} \mathrm{yr}^{-1}$ are obtained, which are comparable to previous soil loss measurements in the area (about $25 \mathrm{t} \mathrm{ha}^{-1} \mathrm{yr}^{-1}$ on average) under similar topographic, land use and climatic settings and with similar temporal and spatial scale. Thus, the technique can be readily employed in well-developed tropical soils to quantify soil loss on agricultural plots, caused by splash and sheet erosion with acceptable accuracy. It is recognized that the basic requirement of this methodology is that top- and sub-soils are homogenized and mixed, prior to onset of the erosion events.

Figure 6 A summary plot showing erosion rates measured at different temporal and spatial scales. Dark grey bars - erosion rates measured within the UUOC by measuring erosional/depositional features (Clark et al., 1998), ${ }^{137} \mathrm{Cs}$ concentrations in soil (Dissanayeke et al., 2010), in-situ cosmogenic nuclides (Hewawasam et al., 2013) and sediment loads in streams (Hewawasam, et al., 2003). Light grey bar - erosion rates reported for market gardens in the Central Highlands by compiling previous erosion rates 
measured in sediment traps (Ministry of Forestry and Environment, 1995, as cited by Gunatilake and Vieth, 2000).

\section{Acknowledgments}

\section{References}

Abegunawaradana, P., Gunathilaka, H.M., 1992. Factors influencing soil conservation decisions by tobacco farmers in Hanguranketa area, Sri Lanka: An application of Tobit model. Tropical Agricultural Research. 4, 270-275.

Alberts, E.E., Moldenhauer, W.C., Foster, G.R., 1980. Soil aggregates and primary particles transported in rill and interrill flow.Soil Sci. Soc. Am. J. 44, 590-595.

Amarasekara, M.G.T.S., Kumarihamy, R.M.K., Dayawansa, N.D.K., De Silva R.P., 2009. The impact of inappropriate soil management on river water quality: A case study in the Kurundu Oya sub catchment of the Upper Mahaweli Catchment, Sri Lanka. Journal of Soil Science Society of Sri Lanka. 49-60.

Ananda, J., Herath, G., Chisholm, A., 2001. Determination of yield and erosion damage functions using subjectively elicited data: application to smallholder tea in Sri Lanka. Aust. J. Agr. Resour. Ec. 45, 275-289.

Clark, R., Manthrithilake, H., White, R., Stocking, M., 1998. Economic valuation of soil erosion and conservation - a case study of Perawella, Sri Lanka. Adv. in Geo. Ecology. $31,879-888$.

Collinsa, A.L., Wallinga, D.E., Sichingabulab, H.M., Leeksc, G.J.L., 2001. Using ${ }^{137}$ Cs measurements to quantify soil erosion and redistribution rates for areas under different land use in the Upper Kaleya River basin, southern Zambia. Geoderma. 104, 299-323.

Correchel, V., Bacchi, O.S.S., De Mari., I.C., Dechen, S.C.F., Reichardt, K., 2006. Erosion rates evaluated by the ${ }^{137} \mathrm{Cs}$ technique and direct measurements on long-term runoff plots under tropical conditions. Soil and Tillage Research. 86, 199-208.

Dadson, S.J., Hovius, N., Chen, H., Dade, W.B., Hsieh, M.L., Willett, S.D., Hu, J.C., Horng, M.J., Chen, M.C., Stark, C.P., Lague, D., Lin, J.C., 2003. Links between erosion, runoff variability and seismicity in the Taiwan orogen. Nature. 426 (6967), 648-651.

Dissanayake, C. K., Mahawatte, P., Abeynayake, K., Weerasekera, T.S.B., 2010. Use of Caesium-137 technique for the assessment of soil erosion in two selected sites in Uma Oya Catchment in Sri Lanka. 19 ${ }^{\text {th }}$ World Congress of Soil Science, Soil Solutions for a Changing World, Brisbane, Australia. 165-168. 
de Vente, J., Poesen, J., 2005. Predicting soil erosion and sediment yield at the basin scale: scale issues and semi-quantitative models. Earth-Science Reviews. 71, 95-125.

Diyabalanage, S., 2012. Study the effectiveness of soil conservation in upper Uma oya sub catchment. BSc in Environmental Science and Natural Resource Management Dissertation, Sabaragamuwa University of Sri Lanka, Unpublished.

El-Swaify, S.A., Krishnarajah, P., 1983. What erosion by water is and what it does, in Carpenter, R.A., ed., Natural systems for development: what planners need to know: New York, Macmillan Publishing Company, pp. 99-161.

Erabadupitiya, 2006. Soil erosion in potato fields. Natural Resource Management Centre, Department of Agriculture, Unpublished report.

Foster, G.R., Meyer, L.D., 1975. Transport of soil particles by shallow flow. Transactions of the ASAE. 15, 99-102.

Foucher, et al., 2014. Increase in soil erosion after agricultural intensification: Evidence from a lowland basin in France. Anthropocene. 7, 30-41

Gunatilake, H.M., Vieth, G.R., 2000. Estimation of on-site cost of soil erosion: a comparison of replacement and productivity change methods. Journal of Soil and Water Conservation. 55, 197-204.

Hasselo, H.N., Sikurajapathy, M., 1965. Estimation of losses and erodibility of tea soils during replanting period. Journal of National Agricultural Society. Ceylon. 2, 3-21.

Hewawasam, T., Von Blanckenburg, F., Schaller, M., Kubik, W., 2003. Increase of human over natural erosion rates in tropical highlands constrained by cosmogenic nuclides. Geology. 31, 597-600.

Hewawasam, T., 2010. Effect of land use in the upper Mahaweli catchment area on erosion, landslides and siltation in hydropower reservoirs of Sri Lanka. J. Natn. Sci. Foundation Sri Lanka. 38, 3-14.

Hewawasam, T., von Blanckenburg, F., Bouchez, J., Dixon, J. L., Schuessler, J. A., Maekeler, R., 2013. Slow advance of the weathering front during deep, supply-limited saprolite formation in the tropical Highlands of Sri Lanka. Geochim. Cosmochim. Acta. 118, 202-230. doi:10.1016/j.gca.2013.05.006.

Illangasinghe, S., Hewawasam, T., 2015. Introducing surface sampling threshold factor for suspended sediment transport: model development using Sri Lankan tropical highland river basins. Hydrol. Res. 46, 136-155. 
Krishnarajah, P., 1982. Soil erosion and conservation in the Upper Mahaweli Watershead, Joachim Memorial Lecture, Annual Sessions of the Soil Science Society of Sri Lanka. p. 9.

Labri`ere, N., Locatelli, B., Laumonier, Y., Freycon, V., Bernoux, M., 2015. Soil erosion in the humid tropics: A systematic quantitative review. Agriculture, Ecosystems and Environment. 203, 127-139.

Mahmood, K., 1987. Reservoir sedimentation: impacts, extent, and mitigation. World Bank Technical Paper 71, Washington, DC. pp. 118.

Manipura, W.P., 1972. Influence of mulch land cover crops on surface run-off and soil erosion in tea lands in the early growth of replanted tea. Tea Quarrerly. 42, 95-102.

NEDECO [Netherlands Engineering Consultants], 1984. Sediment transport in the Mahaweli Ganga: Colombo, Sri Lanka, Unpublished report, Hydrology division, Irrigation Department, pp. 73.

Pandey, C.B., Chaudhari, S.K., 2010. Soil and nutrient losses from different land uses and vegetative methods for their control on hilly terrain of South Andaman. Indian J. Agric. Sci. 80, 399-404.

Pimentel et al., 1995. Environmental and economic costs of soil erosion and conservation benefits. Science. 267, 1117-1123.

Pimentel, D., 2006. Soil Erosion: A food and environmental threat. Environment, Development and Sustainability. 8, 119-137.

Pimentel, D., Burgess M., 2013. Soil Erosion Threatens Food Production. Agriculture. 2013, 3(3), 443-463; doi:10.3390/agriculture3030443.

Phillips, J.D., 2001. The relative importance of intrinsic and extrinsic factors in pedodiversity. Annals of the Association of American Geographers. 91, 609-621.

Phillips, J.D., 2007. Development of texture contrast soils by a combination of bioturbation and translocation. Catena. 70, 92-104.

Quiquereza, A., Brenota, J., Garciac, J.P., Petitc, C., 2008. Soil degradation caused by a high-intensity rainfall event: Implications for medium-term soil sustainability in Burgundian vineyards. Catena. 73, 89-97.

Samarakoon, S.M.M., 2004. An economic assessment of on-site effect of soil erosion due to potato cultivation in Nuwara Eliya district. M.Sc.in Natural Resource Management Dissertation, Postgraduate Institute of Agriculture, University of Peradeniya, Unpublished. 
Samarakoon, S.M.M., Abegunawaradana, P., 1995. An economic assessment of on-site effects of soil erosion in potato lands in Nuwraeliya district of Sri Lanka: Journal of Sustainable Agriculture. 6, 81-93.

Southgate, D., Whitaker, M., 1992. Promoting resource degradation in Latin America: Tropical deforestation, soil erosion, and coastal ecosystem disturbance in Ecuador. Econ. Dev. Cult. Change. 40, 787-807.

Stocking, M., Clark, R., 1999. Soil Erosion and Productivity: Biophysical and FarmerPerspective Assessment on Hillslopes. Mt. Res. Dev.19, 191-202.

Stocking, M.A., Murnaghan, N., 2000. Land degradation - guidelines for field assessment, overseas development group, University of East Anglia, Norwich, UK.

Toy, T.J., Foster, G.R., Renard, K.G., 2002. Soil erosion: processes, predictions, measurements, and control: New York, John Wiley \& Sons, pp. 338.

Vanacker, V., Von Blanckenburg, F., Govers, G., Molina, A., Poesen, J., Deckers, J., Kubic, P., 2007a. Restoring dense vegetation can slow mountain erosion to near natural benchmark levels. Geology. 35, 303-306.

Vanacker, V., von Blanckenburg, F., Hewawasam. T., Kubik, P. W., 2007b. Constraining landscape development of the Sri Lankan escarpment with cosmogenic nuclides in river sediment. Earth Planet. Sci. Lett. 253, 402-414.

Veldkamp, A., 2002. Pedogenesis and Soil Forming Factors. Land use, land cover and soil sciences, in: Verheye, W.H, (Eds.), Land Cover and Land Use in Encyclopedia of Life Support Systems (EOLSS), Developed under the Auspices of the UNESCO, EOLSS Publishers, pp. 64-85.

Verbist, B., Poesen, J., van Noordwijk, M., Widianto Suprayogo, D., Agus, F., Deckers, J., 2010. Factors affecting soil loss at plot scale and sediment yield at catchment scale in a tropical volcanic agroforestry landscape. Catena. 80, 34-46.

Von Blanckenburg, F., Hewawasam, T., Kubik, P., 2004. Cosmogenic nuclide evidence for low weathering and denudation in the wet tropical Highlands of Sri Lanka. J. Geoph. Res. 109, doi10.1029/2003JF000049.

Wallingford, H. R., 1995. Sedimentation Studies in the Upper Mahaweli Catchment Sri Lanka. HR Wallingford Ltd, Oxon, UK, pp. 44.

Wickramagamage, P., 1998, Large-scale deforestation for plantation agriculture in the hill country of Sri Lanka and its impact. Hydrol. Process. 12, 2015-2028. 


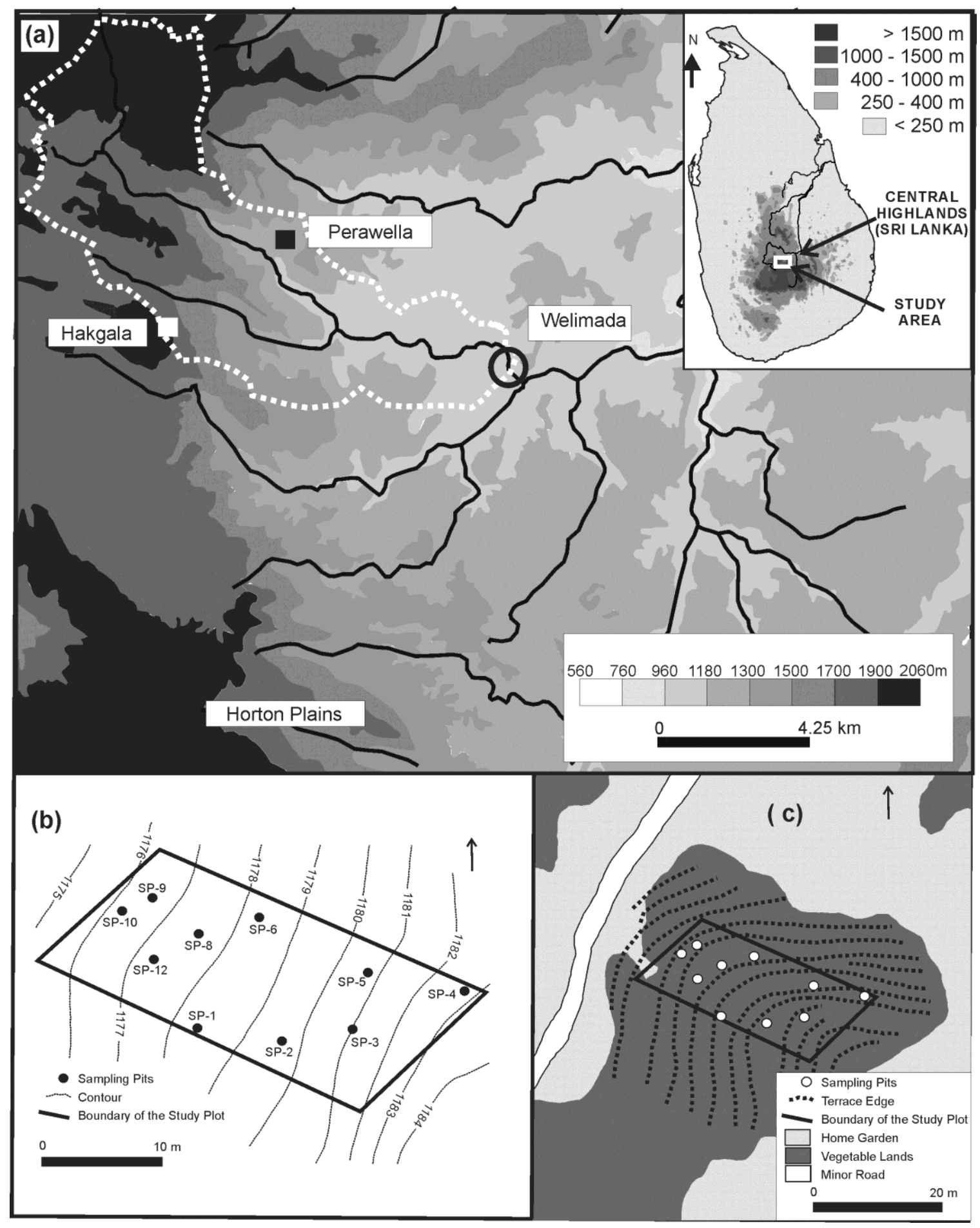




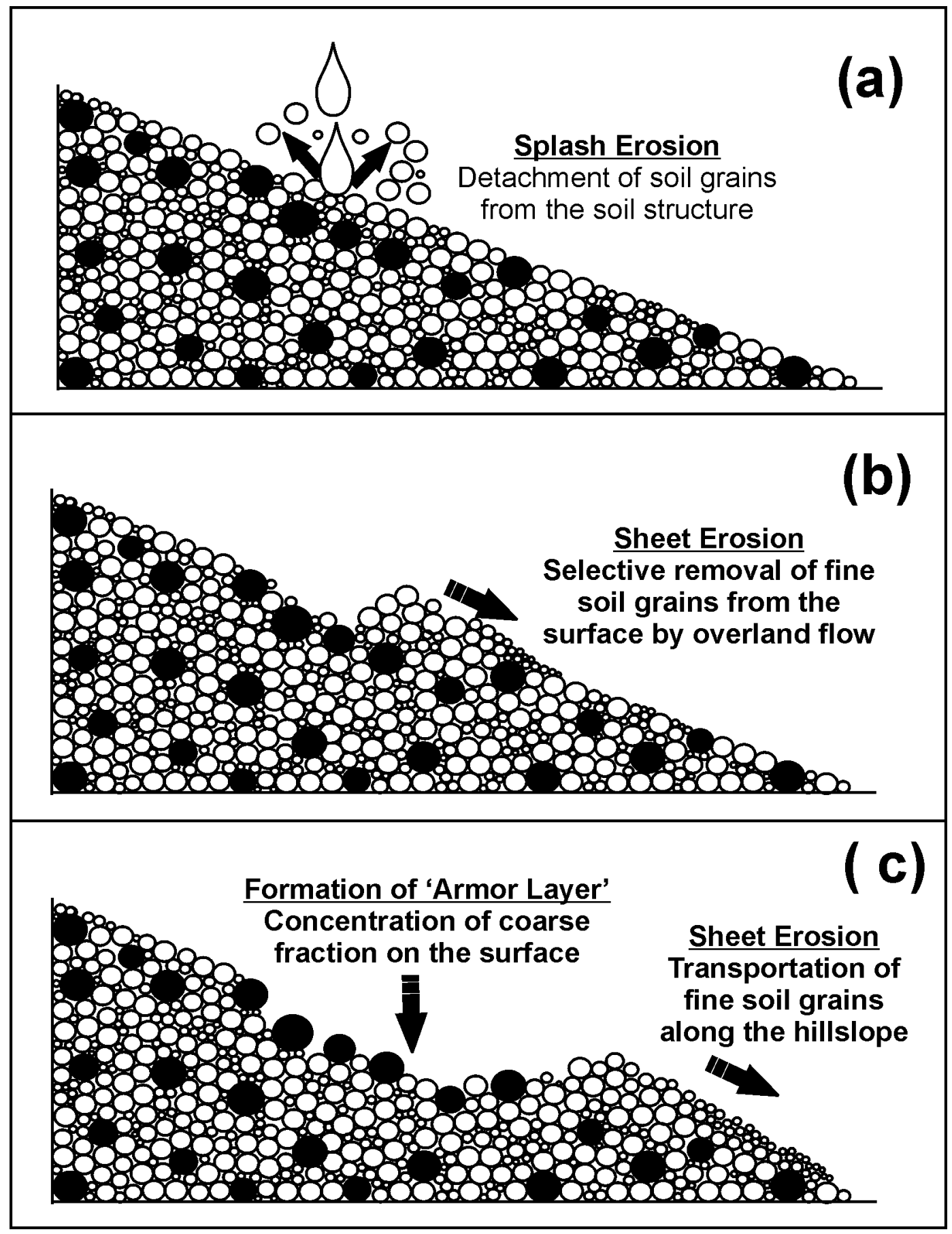




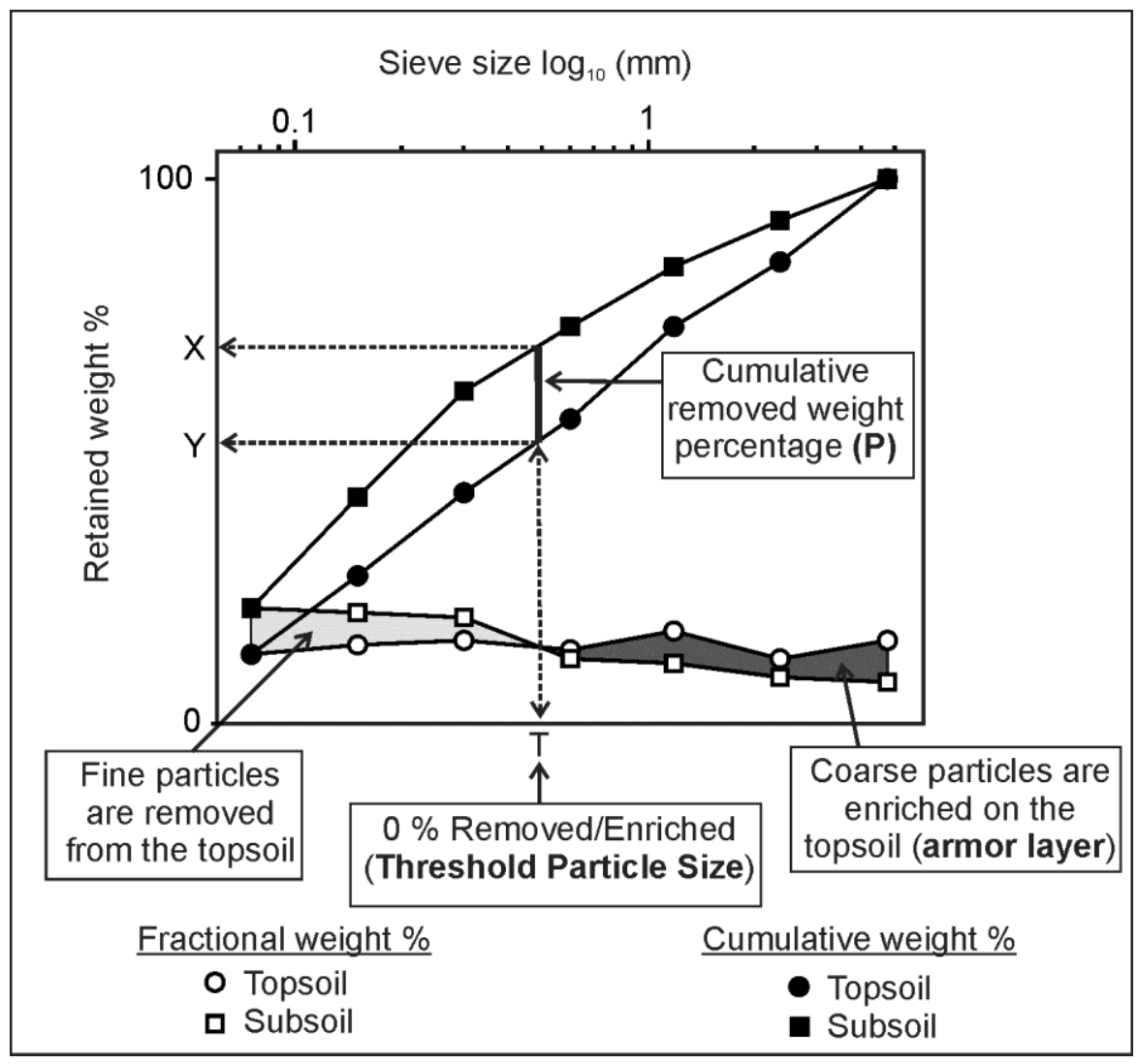




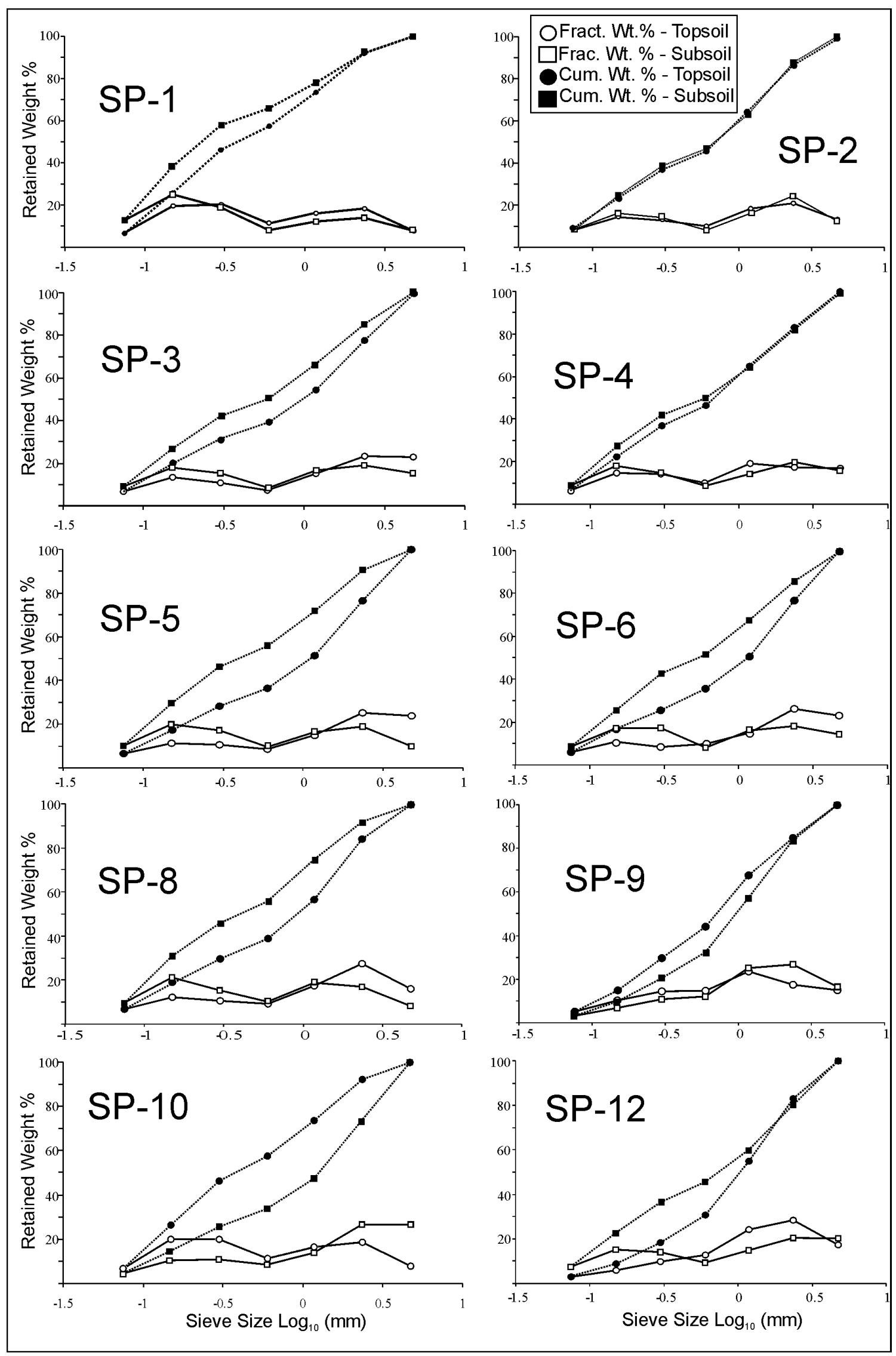




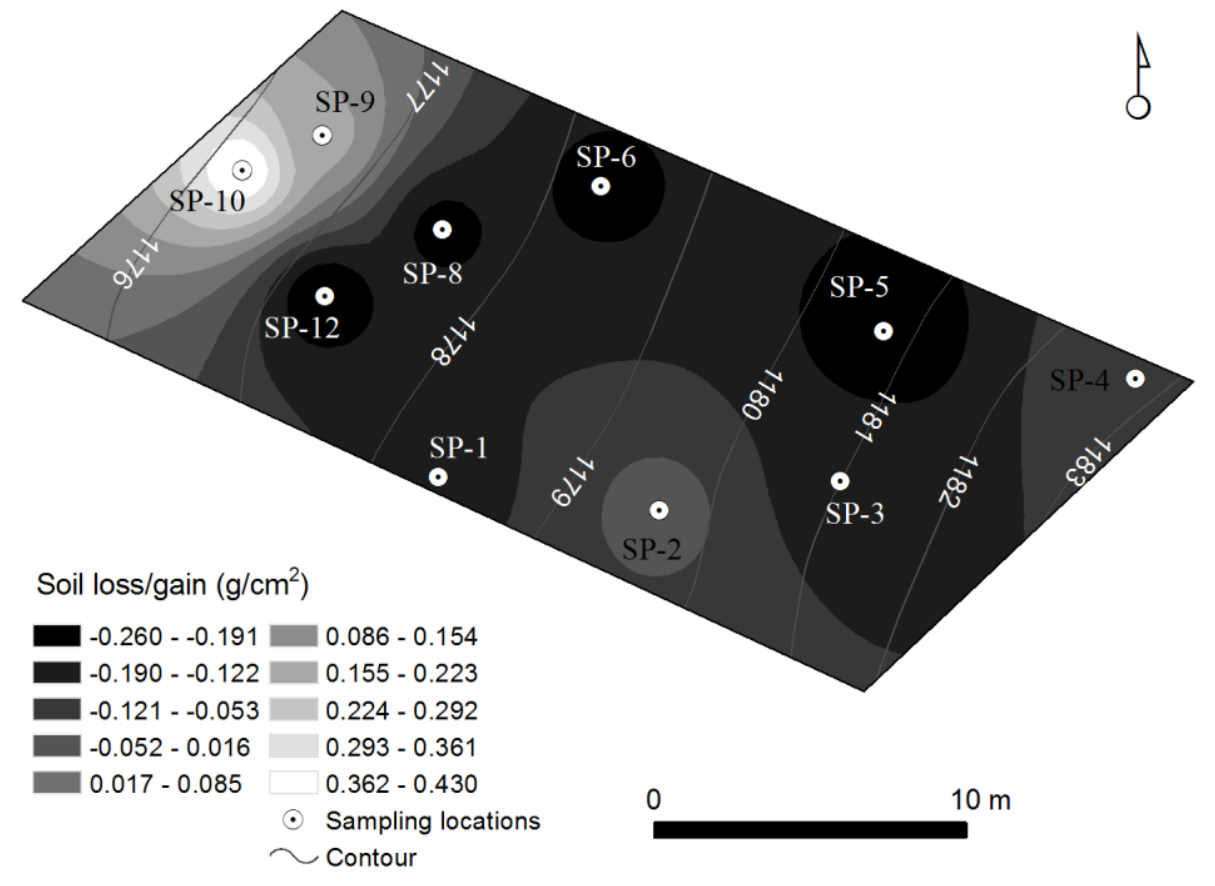




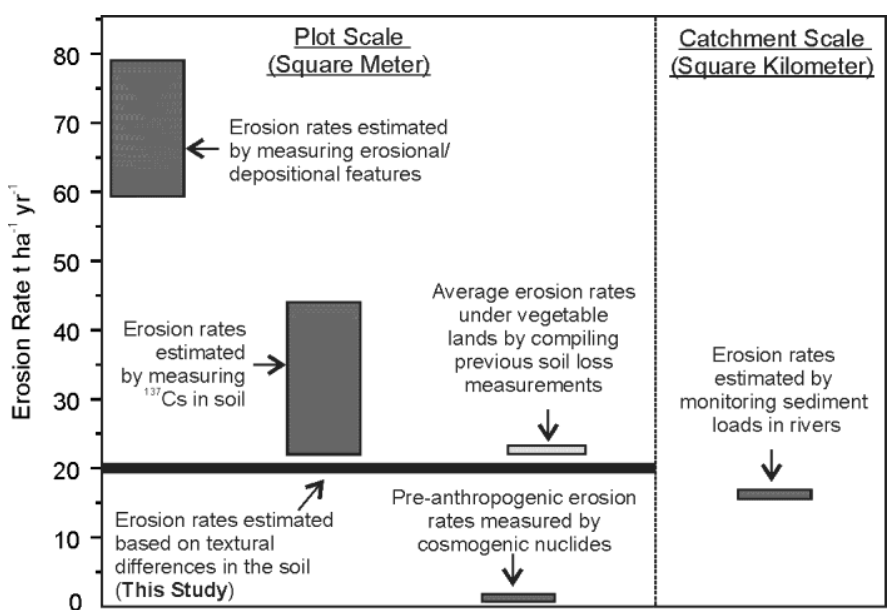

